\title{
Geothermal energy in Denmark
}

\author{
Lars Henrik Nielsen, Anders Mathiesen and Torben Bidstrup
}

The Geological Survey of Denmark and Greenland (GEUS) has for many years been involved with research, advisory and consultancy services concerning the assessment of the geothermal energy potential in Denmark, in close cooperation with private and public partners. The Survey's particular responsibility has been the development of geological models to describe and predict the distribution of sandstone reservoirs suitable for geothermal exploitation. Danish geothermal resources in known sandstone aquifers are estimated to be sufficient to cover household heating requirements in Denmark for more than a century (Sørensen et al. 1998).

\section{Background}

Utilisation of geothermal energy is a well-established technology with more than one hundred plants currently operating in Europe. Concerns with respect to $\mathrm{CO}_{2}$ emission to the global atmosphere have led to increased interest in the utilisation of geothermal energy as one possible way of reducing the consumption of fossil fuels.

In 1983, Dansk Olie \& Naturgas A/S (DONG A/S) was granted a sole concession for the exploration and production of geothermal energy in the entire land area in Denmark. In
Fig. 1. Map of Denmark showing the regional geothermal potential of possible aquifer formations, based on a burial depth of 1000-2500 m and a sand thickness of more than $25 \mathrm{~m}$. White areas in Denmark indicate that the reservoir is not present (Ringkøbing-Fyn High), too shallow (northernmost Jutland), or too deeply buried (central part of Danish Basin). The locations of the Thisted geothermal plant and the new geothermal site at Margretheholm in Copenhagen are shown.

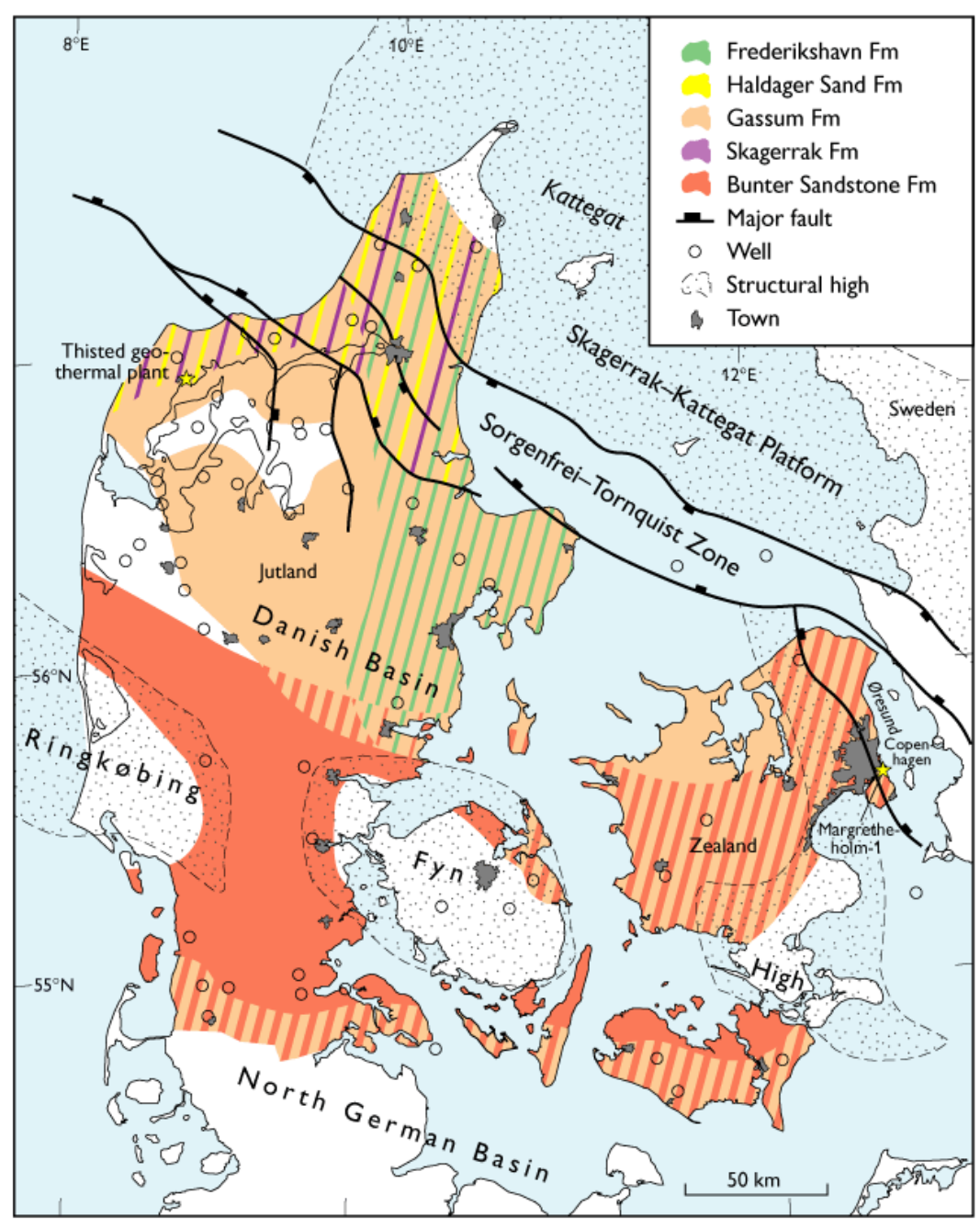




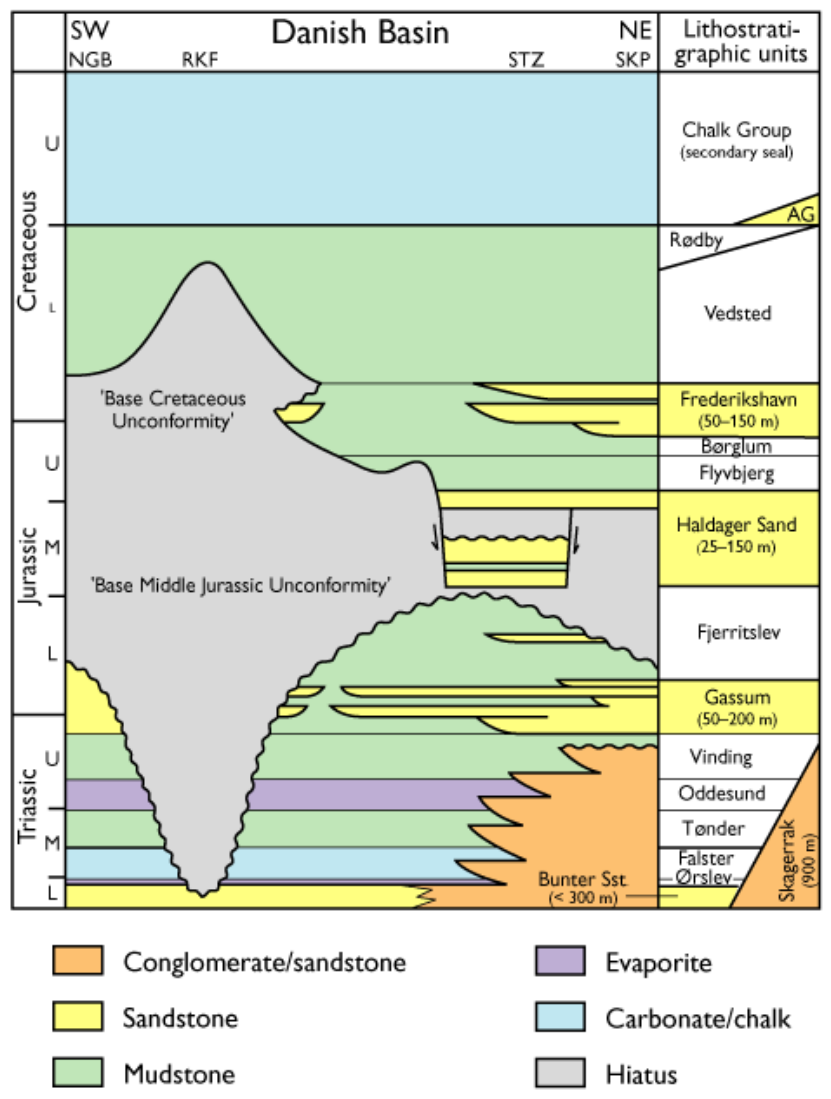

Fig. 2. Generalised stratigraphic scheme of the Danish onshore area along a NW-SE-trending cross-section. The formations with potential aquifers are indicated in yellow and brown. Note the pronounced erosion surfaces at the base of the Middle Jurassic and Lower Cretaceous and the progressive onlap to these surfaces. These features have a major influence on the regional distribution and burial depths of potential reservoirs. AG, Stratigraphic position of the Arnager Grønsand Formation; NGB, North German Basin; RKF, Ringkøbing-Fyn High; SKP, Skagerrak Platform; STZ, Sorgenfrei-Tornquist Zone.

1993 and 2003, selected parts of the concession area were returned to the State in accordance with the licensing terms.

The first comprehensive study of Danish geothermal resources was presented by Michelsen et al. (1981), which incorporates seismic and well data from the Danish onshore areas, with a focus on sandstone aquifers between 2000 and $3000 \mathrm{~m}$ depth. The Survey's contributions to the two volumes of the atlas of geothermal resources published by the Euro-pean Commission (Haenel \& Staroste 1988; Hurter \& Haenel 2002) have presented data and information that identify areas of interest for further geothermal exploration.

Initially it was believed that geothermal heat could be produced from deep, hot aquifers, and in the early 1980s sandstones of the Upper Triassic Gassum Formation were tested at depths of $c .3000 \mathrm{~m}$ in three wells in northern Jutland (Fig. 1). Thick sandstones were encountered, but permeability was insufficient and the results were discouraging. However, technological innovation during the past decade has shifted interest from deep and hot, but high-risk reservoirs, towards shallower aquifers with good porosity and permeability and thus the potential of producing large volumes of warm water. Following heat extraction, the cold water is re-injected into the aquifer at some distance from the producing well via an injection well, in order to maintain reservoir pressure and avoid mixing the cold return water with the warm formation water.

\section{Areas of potential interest}

Four major structural features - the Danish Basin, the Sorgenfrei-Tornquist Zone, the Ringkøbing-Fyn High and the North German Basin - exert the overall control on the geothermal prospectivity of Denmark. They essentially determine the distribution, thickness, facies types and burial depths of the stratigraphic units with potential reservoirs (Fig. 1).

The Danish Basin is bounded by the Ringkøbing-Fyn High to the south and the Sorgenfrei-Tornquist Zone to the north-east. The Upper Permian - Cenozoic basin-fill is 5-6.5 $\mathrm{km}$ thick along the basin axis, increasing locally to more than $9 \mathrm{~km}$ in the Sorgenfrei-Tornquist Zone. The Triassic - Lower Cretaceous succession has a relatively uniform thickness in most of the basin with some thinning towards the Ringkøbing-Fyn High. Due to uplift of most of the basin and the Ringkøbing-Fyn High in early Middle Jurassic time, the Triassic - Lower Jurassic succession is truncated by the 'Base Middle Jurassic Unconformity', which shows a progressively deeper truncation towards the Ringkøbing-Fyn High (Fig. 2). On the high the Lower Jurassic, and in places parts of the Triassic, have been eroded. Regional subsidence gradually took over again in late Middle - early Late Jurassic time and became more widespread, as shown by a progressively younger Upper Jurassic - Lower Cretaceous onlap onto the unconformity towards the high. These events have great influence on the distribution of reservoirs and the thickness of the overburden. Thus, the Lower Triassic reservoirs may be found at moderate depths on the Ringkøbing-Fyn High and along the northern and southern (North German Basin) flanks of the high.

The Sorgenfrei-Tornquist Zone crosses northern Jutland, Kattegat, the northern part of Øresund and southern Sweden. It is a strongly block-faulted zone with tilted Palaeozoic fault blocks overlain by thick Mesozoic deposits (Fig. 1). This zone experienced continuous, but slow, subsidence during the Middle Jurassic regional uplift that affected the Danish Basin and the Ringkøbing-Fyn High, and thick paralic sandstones were deposited in the zone; these sandstones 
form excellent reservoirs (Haldager Sand Formation; Fig. 2). The zone is further characterised by pronounced late Cretaceous - early Tertiary tectonic inversion with the uplift of potential reservoirs.

\section{Potential reservoirs}

The most promising reservoirs occur within the Triassic Lower Cretaceous succession (Fig. 2). This succession has been the target of hydrocarbon exploration since 1935, and is thus known from about 60 deep wells and seismic data acquired over many years, although with a very variable data quality and coverage. Based on regional geological studies (e.g. Bertelsen 1978, 1980; Michelsen et al. 2003; Nielsen 2003) a number of stratigraphic units with a regional geothermal potential have been identified. These include the Lower-Upper Triassic Bunter Sandstone and Skagerrak Formations, the Upper Triassic - Lower Jurassic Gassum Formation, the Middle Jurassic Haldager Sand Formation and the Upper Jurassic - Lower Cretaceous Frederikshavn Formation. Other formations may locally contain potential aquifers, such as the fine-grained sandstones of the F-II Member of the Fjerritslev Formation on the SkagerrakKattegat Platform, and the Arnager Grønsand Formation in easternmost Zealand.

The Bunter Sandstone Formation is present south of the Ringkøbing-Fyn High, on parts of the high and in the Danish Basin. It grades into the Skagerrak Formation towards the north-eastern basin margin (Bertelsen 1978, 1980). The Bunter Sandstone Formation is dominated by fine-grained sandstones, mainly deposited in an arid continental environment dominated by fluvial channels, aeolian dunes and marginal marine facies. The Skagerrak Formation is less well known, but its marginal distribution along the northern and north-eastern basin margin, and the coarsegrained, often poorly sorted sandstones interbedded with claystones, suggest deposition in alluvial fans and lakes.

The Gassum Formation is present in almost the entire Danish area, and shows a remarkable lateral continuity with thickness generally between 100 and $150 \mathrm{~m}$ with a maximum of about $300 \mathrm{~m}$ in the Sorgenfrei-Tornquist Zone (Michelsen et al. 2003; Nielsen 2003). The formation consists of fine- to medium-grained, locally coarse-grained, sandstones interbedded with heteroliths, claystones and thin coals. The laterally continuous shoreface sandstones were deposited by repeated shoreline progradation. Fluvial and estuarine sandstones dominate the lower-middle part of the formation in the Sorgenfrei-Tornquist Zone.

The Haldager Sand Formation is up to $200 \mathrm{~m}$ thick in the Sorgenfrei-Tornquist Zone, and shows a marked thinning towards the south-west and north-east (Michelsen et al.
2003; Nielsen 2003). It consists of thick, fine- to coarsegrained sandstones alternating with thin siltstones, claystones and coals, deposited in shallow marine, estuarine, fluvial and lacustrine environments.

The Frederikshavn Formation is present in the northern part of the Danish area, and shows marked thickness variations $(75-235 \mathrm{~m})$, reaching a maximum in the Sorgenfrei-Tornquist Zone (Michelsen et al. 2003). The formation consists of siltstones and fine-grained sandstones interbedded with claystones.

Temperature and salinity of the formation water in these potential reservoirs increase with increasing depth. The temperature-depth relation is well established, and is rather uniformly developed over the Danish area with a general gradient of about $30^{\circ} \mathrm{C}$ per $\mathrm{km}$. The salinity shows a general increase of about $10 \%$ per $\mathrm{km}$ burial depth, but great variations are found. Porosity and permeability decrease with increasing depth due to mechanical compaction and the formation of diagenetic minerals that reduce pore volume and pore connections. Permeability is very critical, but difficult to predict since very large variations are found depending on depositional facies, provenance, mineralogical composition, burial history and position in the basin. These relationships and their mutual dependency are not fully understood, which weakens the predictive strength of the current geological models used for identifying areas of interest. However, combining the distribution of the above-described formations with an estimate of where sand thickness of the formations exceeds $25 \mathrm{~m}$ at depths of $1000-2500 \mathrm{~m}$ provides a useful indication of regional geothermal potential. Figure 1 displays the potential for the land area of Denmark in a general manner, and indicates which formations may warrant further investigation for geothermal energy production.

\section{Existing and planned geothermal facilities}

The Thisted plant in northern Jutland is the only working geothermal plant in Denmark, although a second plant is currently under construction in Copenhagen (Fig. 1). The Thisted plant has produced heat from the Gassum Formation for almost 20 years without notable production or injection problems.

A study of the geothermal potential in the Copenhagen-Malmö region was initiated in the year 2000 on behalf of DONG A/S encouraged by financial support from the Danish Government and technological developments that make the utilisation of relatively low temperature formation water possible. The subsurface of the greater Copenhagen area was previously poorly known, as no deep wells existed and seismic data coverage was very poor. New seismic data were acquired in 2001, and the Survey has carried out a 


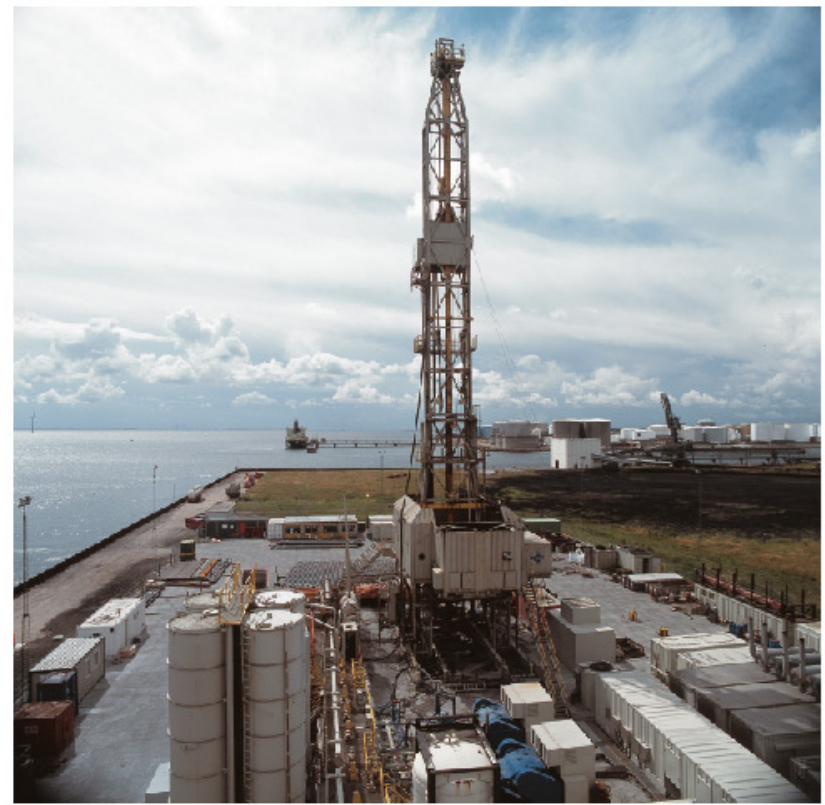

Fig. 3. The drilling of two deep wells at Margretheholm, central Copenhagen.

geological evaluation of the geothermal potential at seven localities in the greater Copenhagen area, based on integration of the new data with existing well and seismic data from Denmark, Øresund and southern Sweden. The evaluation indicated the presence of several possible sandstone aquifers, including the Gassum and Bunter Sandstone Formations. The Margretheholm location close to the centre of Copenhagen was selected for further investigations, and a vertical well was drilled to about $2700 \mathrm{~m}$ in 2002 (Fig. 3). The well encountered a promising aquifer in the Bunter Sandstone Formation, and a second, deviated well was drilled to the same aquifer in 2003. The test results were promising, and a geothermal power plant is now under construction based on the utilisation of $c \cdot 70^{\circ} \mathrm{C}$ geothermal water. When established, the plant is expected to produce around $400 \mathrm{TJ}$ heat annually, corresponding to $1 \%$ of the total heating demand of the Copenhagen area, with an option for future expansion.

As a direct result of the successful efforts in Copenhagen, geothermal exploration has now been resumed in other parts of the onshore Danish area. GEUS is currently cooperating with DONG A/S on the identification and assessment of several prospective sites.

\section{References}

Bertelsen, F. 1978: The Upper Triassic - Lower Jurassic Vinding and Gassum Formations of the Norwegian-Danish Basin. Danmarks Geologiske Undersøgelse Serie B 3, 26 pp.

Bertelsen, F. 1980: Lithostratigraphy and depositional history of the Danish Triassic. Danmarks Geologiske Undersøgelse Serie B 4, 59 pp. Haenel, R. \& Staroste, E. (eds) 1988: Atlas of geothermal resources in the European Community, Austria and Switzerland. Commission of the European Communities, Publication EUR 11026, 74 pp., 110 plates.

Hurter, S. \& Haenel, R. (eds) 2002: Atlas of geothermal resources in Europe. European Commission, Publication EUR 17811, 92 pp., 89 plates.

Michelsen, O. et al. 1981: Kortlægning af potentielle geotermiske reservoirer i Danmark. Danmarks Geologiske Undersøgelse Serie B 5, 28 pp.

Michelsen, O., Nielsen, L.H., Johannessen, P.N., Andsbjerg, J. \& Surlyk, F. 2003: Jurassic lithostratigraphy and stratigraphic development onshore and offshore Denmark. In: Ineson, J.R \& Surlyk, F. (eds): The Jurassic of Denmark and Greenland. Geological Survey of Denmark and Greenland Bulletin 1, 147-216.

Nielsen, L.H. 2003: Late Triassic - Jurassic development of the Danish Basin and the Fennoscandian Border Zone, southern Scandinavia. In: Ineson, J.R \& Surlyk, F. (eds): The Jurassic of Denmark and Greenland. Geological Survey of Denmark and Greenland Bulletin 1, 459-526.

Sørensen, K., Nielsen, L.H., Mathiesen, A. \& Springer, N. 1998: Geotermi i Danmark: Geologi og ressourcer. Danmarks og Grønlands Geologiske Undersøgelse Rapport 1998/123, 24 pp.

\section{Authors' address}

Geological Survey of Denmark and Greenland, Øster Voldgade 10, DK-1350 Copenhagen K, Denmark. E-mail: Ihn@geus.dk 